\title{
The Elasticity of Intertemporal Substitution: New Evidence from 401(k) Participation
}

\author{
Gary V. Engelhardt and Anil Kumar \\ Research Department \\ Working Paper 0812
}

Federal Reserve Bank of Dallas 


\title{
The Elasticity of Intertemporal Substitution: New Evidence from 401(k) Participation
}

\author{
Gary V. Engelhardt* \\ Syracuse University \\ Anil Kumar \\ Federal Reserve Bank of Dallas
}

\begin{abstract}
A key parameter in economics is the elasticity of intertemporal substitution (EIS), which measures the extent to which consumers shift total expenditures across time in response to changes in the effective rate of return. In contrast to the previous literature, which primarily has relied on Euler equation methods and generated a wide range of estimates, we show how a life-cycle-consistent econometric specification of employee 401(k) participation along with plausibly exogenous variation in rates of return due to employer matching contributions can be used to generate new estimates of the EIS. Because firms often cap the generosity of the match, employer matching generates non-linearities in household budget sets. We draw on non-linear budget-set estimation methods rooted in the public economics literature, and using detailed administrative contribution, earnings, and pension-plan data for a sample of 401(k)-eligible households from the Health and Retirement Study, we estimate the EIS to be 0.74 in our richest specification, with a 95\% confidence interval that ranges from 0.37 to 1.21 .
\end{abstract}

*Corresponding author. Engelhardt is Associate Professor, Department of Economics, and Senior Research Associate, Center for Policy Research, Syracuse University (gvengelh@maxwell.syr.edu). Kumar is an economist in the Research Department at the Federal Reserve Bank of Dallas (anil.kumar@dal.frb.org).We thank Claudia Sahm and the seminar participants at the Federal Reserve Board of Governors for helpful comments. All research with the restricted-access data from the Health and Retirement Study was performed under agreement in the Center for Policy Research at Syracuse University and the Federal Reserve Bank of Dallas. We are especially grateful to Bob Peticolas and Helena Stolyarova for their efforts in helping us understand the HRS employer-provided pension-plan data. The research reported herein was supported (in part) by a grant from the TIAA-CREF Institute and (in part) by the Center for Retirement Research at Boston College pursuant to a grant from the U.S. Social Security Administration funded as part of the Retirement Research Consortium. Various portions of the underlying data construction were funded by the Center for Policy Research at Syracuse University, the Economics Program, National Science Foundation, under Grant No. SES-0078845, National Institute on Aging, under Grant No. 1 R03 AG19895-01, and the U.S. Department of Labor. The opinions and conclusions are solely those of the authors and should not be construed as representing the opinions or policy of the Social Security Administration, Federal Reserve Bank of Dallas, Federal Reserve System, any agency of the Federal Government, Center for Retirement Research at Boston College, TIAA-CREF, United States Department of Labor, National Science Foundation, National Institute on Aging, or Syracuse University. All errors are our own. 


\section{Introduction}

A key parameter in economics is the elasticity of intertemporal substitution (EIS), which measures the extent to which consumers shift total expenditures across time in response to changes in the effective rate of return. The EIS plays a central role in studies of consumption and asset pricing, as well as the positive and normative analyses of the impact of taxation on saving behavior. Unfortunately, the empirical evidence on this elasticity, much of which has relied on Euler-equation studies of consumption, is mixed (Browning and Lusardi, 1996). For example, the well-known papers by Hall (1988) and Dynan (1993) suggest point estimates of the EIS for the United States that are small or close to zero, while others find larger point estimates: Skinner (1985), from 0.3 to 0.5; Blundell, Meghir, and Neves (1993), 0.5; Attanasio and Weber (1995), from 0.6 to 0.7 ; Vissing-Jorgensen (2002), from 0.3 to 1; Ziliak and Kniesner (2005), from 0.7 to 1; and Mulligan (2002), Gruber (2006), and Vissing-Jorgensen and Attanasio (2003), from 1 to 2, among others.

Although some of the differences across studies likely can be linked to differences in the type of data used (aggregate time-series, cohort, or household-level), the specification of preferences and heterogeneity, the treatment of limited asset-market participation, and taxation, one important concern with many existing studies is that there is rather limited independent variation in rates of return with which to identify estimates of the EIS. ${ }^{1}$ For example, the EIS in Euler-equation studies often is identified primarily by time-series variation in interest rates, but the underlying economic factors that move

\footnotetext{
${ }^{1}$ For analyses of the sensitivity of estimates to the type of data used, see Attanasio and Weber (1993, 1995); the specification of preferences and heterogeneity, see Attanasio and Weber (1989) and Attanasio and Browning (1995); the treatment of limited asset-market participation, see Attanasio, Banks, and Tanner (2002), Vissing-Jorgensen (2002), and Vissing-Jorgensen and Attanasio (2003); taxation, see Mulligan (2002), Gruber (2006), Vissing-Jorgensen and Attanasio (2003) and Ziliak and Kniesner (2005).
} 
interest rates may also affect consumption decisions. The usefulness of instrumentalvariable (IV) techniques that attempt to circumvent this difficulty by drawing on lagged values of the interest rate from the information set may be limited if shocks to capital markets are persistent, but slow moving (Gruber, 2006). ${ }^{2}$ Carroll (2001), Ludvigson and Paxson (2001), and Yogo (2004) discuss more general problems with Euler-equation estimation.

In contrast to the existing literature, we take a novel approach and show how a detailed life-cycle-consistent econometric specification of employee 401(k) participation can be used to generate new estimates of the EIS. The key to our approach is that many employers that sponsor 401(k) plans also match employee contributions. A typical match might be 50 cents for each dollar of contribution, up to a maximum percentage of pay, say, 6 percent. Because there is substantial variation across firms in matching schemes, as we document in the analysis below, employer matching provides large, plausibly exogenous cross-sectional variation in the effective rate of return that can be used to identify the EIS.

We begin by using the necessary conditions for optimal tax-deferred saving to derive a life-cycle-consistent econometric specification for 401(k) participation. Because firms often cap the generosity of the match, employer matching generates non-linearities in household budget sets. We draw on non-linear budget-set estimation methods rooted in the public economics literature and applied in a companion paper, Engelhardt and Kumar (forthcoming), and apply them to a sample of 1,042 individuals in 1991 eligible for 401(k) plans in the Health and Retirement Study (HRS). To circumvent difficulties with measurement error in 401(k) participation and matching incentives, we use

\footnotetext{
${ }^{2}$ Gruber (2006) discusses these issues of identification in detail.
} 
administrative data from three sources: contributions from W-2 earnings records provided by the Social Security Administration (SSA) and Internal Revenue Service (IRS); detailed matching formulas from pension Summary Plan Descriptions (SPD) provided by the employers of HRS respondents; and, a combination of Social-Security-coveredearnings histories for 1951-1991 and W-2 earnings for 1980-1991, pension SPDs, and pension-benefit calculators to measure lifetime earnings that are used to construct key variables in our empirical specifications.

Our estimates from the life-cycle-consistent discrete choice regression specifications for $401(\mathrm{k})$ participation indicate an EIS of 0.74 for our richest specification. The $95 \%$ confidence interval ranges from 0.37 to 1.21 , so that, at conventional significance levels, we can reject the null hypothesis that the EIS is zero, but cannot reject the null hypothesis that the EIS is 1 , the latter of which is associated with $\log$ utility.

Although based on a fundamentally different approach than in the existing literature and a sample limited to older workers eligible for a $401(\mathrm{k})$, our results are generally consistent with the recent Euler-equation estimates of the EIS of Attanasio and Weber (1995) and Ziliak and Kniesner (2005). Because many workers with 401(k)s invest in equities in their accounts, our results are also consistent with the findings of Attanasio, Banks, and Tanner (2002), Vissing-Jorgensen (2002), and Vissing-Jorgensen and Attanasio (2003) that the EIS for stockholders is high. In addition, those studies treated asset ownership as exogenous, whereas our estimate of the EIS comes from the estimation of the decision to own tax-deferred assets itself. Finally, our results are 
substantially larger than the highly-cited experimental findings from the HRS of Barsky, Kimball, Juster, and Shapiro (1997), who estimated an EIS of 0.18.

The paper is organized as follows. Because our approach relies on employer matching as the basis for identification, we begin by describing our data and the variation in employer matching schemes in section 2. In section 3, we lay out a detailed theoretical framework that models the budget set defined by employer matching and the tax treatment of 401(k) saving as twice continuously differentiable and derive the firstorder conditions from the consumer's optimization. Then in section 4, we use these conditions to derive a life-cycle-consistent econometric specification for 401(k) participation from which we can recover the EIS. We discuss issues in estimation, measurement, and identification in section 5 and present the new estimates of the EIS in section 6. There is a brief conclusion.

\section{Data and Descriptive Statistics on Employer Matching}

Our sample is based on 1,042 individuals eligible to contribute to a 401(k) in 1991 from the first wave of the HRS, a nationally representative random sample of 51-61 year olds and their spouses (regardless of age). The HRS asked detailed questions about wealth, demographics, and spousal characteristics in 1992, and household income, tax information, and IRA contributions in 1991. Furthermore, the HRS collected SPDs, which are legal descriptions of pensions written in plain English, from employers of HRS respondents for all current and previous jobs in which the respondent was covered by a pension. The SPDs give the employer matching formula. This allows us to measure the exact incentives to contribute. 
We placed four restrictions on the sample. First, because there are four types of employer matching-fixed-rate, discretionary, profit-sharing, and variable-rate matching — and the extent of matching is not always known in advance to employees making deferral decisions in profit-sharing and discretionary plans, we excluded these plans from our sample. Second, we used the SPDs to construct the complete schedule of employer matching contributions for each individual in our sample and applied all relevant restrictions on plan eligibility in the SPD, including those due to tenure, hours, earnings, age, and vesting of the employer matching contributions. Third, we identified the job in which the respondent was employed in 1991, and then SPDs associated with that job that had dates of adoption after 1991 were excluded. In addition, we used the date of last amendment and dates for changes in plan provisions indicated in the text of the SPD to exclude plans that were in existence in 1991 but whose features changed between 1991 and the time the SPD was collected. Finally, we kept SPDs only for workers with linked administrative earnings data, described below.

Therefore, based on our sample, Tables 1 and 2 provide selected descriptive statistics on employer matching. Table 1 shows the distribution of employer match rates for the 372 workers in plans that match; the remaining 670 workers were in plans that did not offer matching. Columns 1 and 2 indicate that these match rates were clustered at 25, 50, and 100 percent, where the median match rate was 50 percent. However, 27 percent of the plans offered matches of 100 percent, and three plans offered match rates of 200 percent. Because many firms limit the amount of the match, Table 2 shows the distribution of matching caps in the analysis sample, expressed as a percent of annual 
pay. Although the median cap was 6 percent of pay, 15 percent of plans had higher caps, and 19 percent had caps of less than 4 percent.

\section{Theoretical Framework}

There are two key implications of these tables. First, there is substantial crosssectional variation in incentives to save based on employer matching. Indeed, this variation is an order of magnitude larger than either typical time-series movements in interest rates or cross-sectional variation in after-tax rates of return used to identify Eulerequation estimates. Second, the caps on matching generate kinks in the household budget set. In this section, we lay out a theoretical framework that incorporates employer matching into the intertemporal allocation decision. ${ }^{3}$ Then in section 4 below, we lay out estimation techniques rooted in the public economics literature that account for these kinks in the budget set.

\subsection{Set-up}

We make the following assumptions:

1) Intratemporal direct utility, $U(C, l ; \mathbf{z})$, is derived from leisure, $l$, with an associated price, $q^{l}$, consumption of a composite good, $C$, with an associated price, $q^{c}$, and a vector of demographics, $\mathbf{z}$, and is intratemporally weakly separable and intertemporally additively separable. Because consumption and hours are not fully observed in the HRS, we work with the indirect, rather than the direct, utility function. Specifically, let $V(\mathbf{q}, y ; \mathbf{z})$ be the intratemporal indirect utility function. It takes as arguments the vector of prices of leisure and consumption, $\mathbf{q}$, full income, $y$, and the vector of demographics, $\mathbf{z}$.

\footnotetext{
${ }^{3}$ Second, to keep the model tractable and because the $E I S$ is only defined for a stable set of preferences and is based on a neo-classical approach to consumer behavior, we have assumed full rationality in choices, perfect information, no fixed costs, and ignored other anomalies highlighted in the behavioral economics approach, such as inertia and passivity, that recently have been argued to be important determinants of 401(k) participation (Choi, Laibson, Madrian, and Metrick, 2002, 2003, 2004).
} 
2) The consumer faces a per period probability of survival of $\rho$, with period $\mathrm{K}$ being the known maximum length of life, and with probability $1-\rho$, the consumer dies and receives the terminal payoff $\Phi\left(W^{T}\right)$, the utility of bequests, which is a function of total wealth, $W^{T}$; The lifetime is composed of two parts: from period $\mathrm{N}$ to $\mathrm{K}$, the consumer is retired and no hours of labor are supplied to the market, so leisure equals the time endowment, and from period 0 to $\mathrm{N}-1$, the consumer works, and the timing of retirement in period $\mathrm{N}$ is endogenous;

3) Total wealth is accumulated in three forms when working: retirement-account wealth, defined as the sum of IRA, 401(k), and non-401(k) DC wealth, $W^{R A} \equiv W^{I R A}+W^{D C}+W^{401 k}$; employer-provided defined-benefit pensions and Social Security, $W^{D B}$; and taxable assets, $W^{T A} .{ }^{4}$ Let $s^{h}$ be the beginning-ofperiod share of total wealth in asset type $h, h=R A, T A, D B$. Defined-benefit pension wealth evolves as $W_{t+1}^{D B}=\left(1+\alpha_{t}^{D B}\right) s_{t}^{D B} W_{t}^{T}$, where $\alpha^{D B}$ is the pension accrual.

\subsection{Retirement Accounts}

There are minimum- and maximum-contribution constraints on 401(k)s and IRAs (with multipliers in square brackets), respectively,

$$
\begin{array}{ll}
Q_{t}^{401(k)} \geq 0, & {\left[\eta_{t}^{0}\right]} \\
Q_{t}^{401(k)} \leq L_{t}^{401(k)}, & {\left[\eta_{t}^{L}\right]} \\
Q_{t}^{I R A} \geq 0, & {\left[v_{t}^{0}\right]}
\end{array}
$$

and

$$
Q_{t}^{I R A} \leq L_{t}^{I R A}
$$$$
\left[v_{t}^{L}\right]
$$

where $L_{t}^{401(k)}$ and $L_{t}^{I R A}$ are the upper limits on $401(\mathrm{k})$ and IRA contributions, respectively. Let $M$ be the employer's matching contribution in dollars on the employee's 401(k) contribution, $Q^{401(k)}$, where $M_{t}=M\left(Q_{t}^{401(k)}, y_{t}^{l}, \mathbf{m}_{t}\right)$ is twice

\footnotetext{
${ }^{4}$ We abstract here from a treatment of housing, but, in Engelhardt and Kumar (2006), we expand the model to include a detailed treatment of housing equity and constraints on mortgage borrowing. Those extensions do not affect the results in the current analysis.
} 
continuously differentiable, $y^{l}$ is labor earnings, and $\mathbf{m}$ is a vector of plan-specified match rates. There are the following minimum and maximum constraints on IRA withdrawals, with multipliers in square brackets:

$$
\begin{array}{ll}
Q_{t}^{I R A W} \geq D_{t}^{\text {Age70-1/2 }} \cdot \frac{W_{t}^{I R A}}{h_{t}}, & {\left[\varphi_{t}^{0}\right]} \\
Q_{t}^{I R A W} \leq W_{t}^{I R A} . & {\left[\varphi_{t}^{L}\right]}
\end{array}
$$

Equation (6) states that the withdrawal cannot exceed the beginning-of-period IRA wealth. ${ }^{5}$

Retirement wealth can be invested either in bonds, with riskless pre-tax return $r^{B}$, or in stocks, with a risky pre-tax return

$$
\tilde{r}_{t}^{S}=\frac{1+\tilde{g}_{t}+d}{1+\pi}-1
$$

where $\pi$ is the constant inflation rate, $d$ is the constant nominal dividend yield, and $\tilde{g}$ is the stochastic nominal capital gain earned from the beginning of period $t$ to the beginning of period $t+1$. Let $R^{R A}$ be the weighted-average return on wealth in retirement accounts,

$$
R_{t}^{R A} \equiv\left(1-\vartheta_{t}^{R A}\right)\left(1+r_{t}^{B}\right)+\vartheta_{t}^{R A}\left(1+\tilde{r}_{t}^{S}\right)
$$

where $\vartheta^{R A}$ is the share of retirement-account wealth invested in stocks. Then retirementaccount wealth evolves as

$$
W_{t+1}^{R A}=R_{t}^{R A}\left[s_{t}^{R A} W_{t}^{T}+F_{t}+Q_{t}^{401(k)}+M_{t}+Q_{t}^{I R A C}-Q_{t}^{I R A W}\right]
$$

\footnotetext{
${ }^{5}$ In (5), $D^{\text {Age } 70-1 / 2}$ is a dummy variable that is one if the individual is age $70 \frac{1 / 2}{2}$ or older and is zero otherwise, and $h$ is the individual's life expectancy. Thus, if under age $70 \frac{12}{2}$, the withdrawal must be greater than or equal to zero, and, if age $70^{1 / 2}$ or older, the withdrawal must satisfy the minimumdistribution requirements under federal law that are a function of life expectancy.
} 
where $F$ is the employer's non-matching contribution for the plan. ${ }^{6}$

\subsection{Taxable Assets}

The equation of evolution for taxable assets is

$$
W_{t+1}^{T A}=R_{t}^{T A}\left[s_{t}^{T A} W_{t}^{T}+w_{t}\left(L^{l}-l_{t}\right)+y_{t}^{o}-q_{t}^{c} C_{t}-Q_{t}^{401(k)}-Q_{t}^{I R A C}+Q_{t}^{I R A W}-T_{t}\right],
$$

where $R^{T A}$ is the return on taxable wealth,

$$
R_{t}^{T A} \equiv\left(1-\vartheta_{t}^{T A}\right)\left(1+r_{t}^{B}\right)+\vartheta_{t}^{T A}\left(1+\tilde{r}_{t}^{S}\right),
$$

$\vartheta^{T A}$ is the share of taxable wealth invested in stocks, $y^{o}$ is other income, $w$ is the gross hourly wage rate, $L^{l}$ is the leisure endowment, and $w\left(L^{l}-l\right) \equiv y^{l}$ is labor earnings. In (10), $T$ is the sum of income and payroll taxes, and the IRA early withdrawal penalty. We model $T$ as a twice continuously differentiable function of federal taxable income, non-qualified IRA withdrawals, and deductible IRA contributions, $\zeta_{t} Q_{t}^{I R A C}$, where $\zeta$ is the fraction of IRA contributions that is tax-deductible.

\subsection{Constraints}

Equations (9), (10), and the DB accrual equation above sum to yield the intertemporal budget constraint that determines $W_{t+1}^{T}$. In addition to the constraints on IRA withdrawals, 401(k) and IRA contributions, there are two other important constraints on behavior. First, there is a liquidity constraint,

$$
W_{t}^{T A} \geq 0
$$

\footnotetext{
${ }^{6}$ These would be contributions the employer makes on a periodic basis, as specified in the SPD, but are not related to any voluntary or mandatory contributions by the employee: for example, those defined as a percentage of pay in a money purchase plan or as a function of some measure of firm performance in a profit-sharing plan.
} 
such that total per period full expenditure (also referred to as "full income" in the twostage budgeting literature), $y$, defined as

$$
y_{t} \equiv q_{t}^{c} C_{t}+w_{t} l_{t},
$$

must be less than or equal to total net cash on hand, $X$, defined as beginning-of-period liquid taxable wealth and other income on hand, plus the market value of the leisure endowment, less the tax liability, less any tax-deferred saving, plus any IRA wealth made liquid through a withdrawal:

$$
X_{t} \equiv W_{t}^{T A}+y_{t}^{o}+w_{t} L^{l}-T_{t}-Q_{t}^{401(k)}-Q_{t}^{I R A C}+Q_{t}^{I R A W} .
$$

Let $\mu_{t}$ be the associated Kuhn-Tucker multiplier. We assume that DB, DC, and 401(k) wealth are illiquid until retirement and cannot be used as collateral, but we allow IRA withdrawals when working

Second, the consumer must decide which assets to hold in taxable and taxdeferred forms, where there are constraints on the shares of retirement-account and taxable assets allocated to stocks:

$$
\begin{array}{lc}
\vartheta_{t}^{R A} \geq 0, & {\left[\varpi_{t}^{0}\right]} \\
\vartheta_{t}^{R A} \leq 1, & {\left[\varpi_{t}^{L}\right]} \\
\vartheta_{t}^{T A} \geq 0, & {\left[\chi_{t}^{L}\right]}
\end{array}
$$

and

$$
\vartheta_{t}^{T A} \leq 1
$$$$
\left[\chi_{t}^{L}\right]
$$

To summarize, the only forms of "active" saving when working are through contributions to 401(k), IRA, or taxable assets. However, the primary technology for smoothing resources across periods when working is through taxable-asset saving, 
because 401(k) saving is illiquid; IRA contributions are not necessarily illiquid because of the availability of withdrawals, but IRA withdrawals may incur a tax penalty; and traditional pensions and Social Security are illiquid. This means that the consumer's optimization does not imply automatically that all active saving be allocated first to the tax-preferred asset with the highest net return, because, in the face of uncertainty, the consumer must balance the desire for a high return with the need for liquidity. ${ }^{7}$

\subsection{First-Order Conditions}

Each period when working, the consumer chooses consumption, leisure, voluntary 401(k) contributions, IRA contributions, IRA withdrawals, and the shares of retirementaccount and taxable wealth held in risky stocks, respectively. ${ }^{8}$ Following Browning, Deaton, and Irish (1985), let $V_{t}^{*}\left(W_{t}^{T}\right)$ be the sum of current and future expected utility based on total wealth in period $t$. The individual makes all decisions at the beginning of the period, based on the information set, $\Omega_{t}$, after which, $r^{s}$ is realized, $E$ is the expectations operator conditional on the information set, and $\beta$ is the discount rate.

We express the optimization in terms of two-stage budgeting. ${ }^{9}$ In the first-stage, the individual chooses full income, dis-saving through IRA withdrawals, and the portfolio allocations to stock of retirement-account and taxable wealth, and must allocate total "active" saving to three asset categories—401(k), IRA, and taxable assets— to maximize the expected present discounted value of lifetime indirect utility. In the second

\footnotetext{
${ }^{7}$ Engelhardt and Kumar (forthcoming) discuss this in detail.

${ }^{8}$ Each period when retired, the consumer chooses consumption, IRA contributions, IRA withdrawals, and receives eligible pension and Social Security benefits.

${ }^{9}$ The necessary condition for two-stage budgeting is that utility be weakly separable (Gorman, 1959). The model assumes strongly intertemporally and weakly intratemporally separable preferences, so that a twostage budgeting interpretation is valid.
} 
stage, optimal full income, $y^{*}$, in each period is allocated statically between the goods that enter direct utility: consumption and leisure. Then for any time $t, t<\mathrm{N}$, the dynamic optimization problem can be written as

$$
\begin{aligned}
\mathscr{V}_{t}^{*}\left(W_{t}^{T}\right)=\max _{\{\mathbf{c}\}}\{ & V\left(\mathbf{q}_{t}, y_{t} ; \mathbf{z}\right)+E_{t}\left[\rho_{t} \beta V_{t+1}^{*}\left(W_{t+1}^{T}\right)+\left(1-\rho_{t}\right) \beta \Phi\left(W_{t+1}^{T}\right)\right]+\mu_{t}\left(X_{t}-y_{t}\right) \\
& +\eta_{t}^{L}\left(L_{t}^{401(k)}-Q_{t}^{401(k)}\right)+\eta_{t}^{0}\left(Q_{t}^{401(k)}-0\right) \\
& +v_{t}^{L}\left(L_{t}^{I R A C}-Q_{t}^{I R A C}\right)+v_{t}^{0}\left(Q_{t}^{I R A C}-0\right)+\varphi_{t}^{L}\left(W_{t}^{I R A}-Q_{t}^{I R A W}\right) \\
& +\varphi_{t}^{0}\left(Q_{t}^{I R A W}-D_{t}^{A g e 70-1 / 2} \cdot\left(W_{t}^{I R A} / h_{t}\right)\right) \\
& \left.+\varpi_{t}^{L}\left(1-\vartheta_{t}^{R A}\right)+\varpi_{t}^{0}\left(\vartheta_{t}^{R A}-0\right)+\chi_{t}^{L}\left(1-\vartheta_{t}^{T A}\right)+\chi_{t}^{0}\left(\vartheta_{t}^{T A}-0\right)\right\},
\end{aligned}
$$

where c contains the choice variables: $y_{t}, Q_{t}^{V O L}, Q_{t}^{I R A C}, Q_{t}^{I R A W}, \vartheta_{t}^{R A}, \vartheta_{t}^{T A}$.

The first-order conditions when working for 401(k) contributions, IRA contributions, and full income can be expressed as

$$
\begin{aligned}
\eta_{t}^{L}-\eta_{t}^{0} & \left.=E_{t}\left\{R_{t}^{R A}\left(1+M_{Q_{t}^{401 k}}\right)-R_{t}^{T A}\left(1-T_{I t}\left(1-\zeta_{y^{\prime}} Q_{t}^{I R A}\right)\right)\right] \cdot\left[\rho_{t} \beta V_{W_{t+1}^{T}}^{*}+\left(1-\rho_{t}\right) \beta \Phi_{W_{t+1}^{T}}\right]\right\} \\
& -\mu_{t}\left(1-T_{I t}\left(1-\zeta_{y^{\prime}} Q_{t}^{I R A}\right)\right), \\
v_{t}^{L}-v_{t}^{0}= & E_{t}\left\{\left[R_{t}^{R A}-R_{t}^{T A}\left(1-T_{I t} \zeta_{t}\right)\right] \cdot\left[\rho_{t} \beta V_{W_{t+1}^{T}}^{*}+\left(1-\rho_{t}\right) \beta \Phi_{W_{t+1}^{T}}\right]\right\}-\mu_{t}\left(1-T_{I t} \zeta_{t}\right),
\end{aligned}
$$

and

$$
V_{y}\left(\mathbf{q}_{t}, y_{t} ; \mathbf{z}\right)=E_{t}\left\{R_{t}^{T A}\left[\rho_{t} \beta V_{W_{t+1}^{T}}^{*}+\left(1-\rho_{t}\right) \beta \Phi_{W_{t+1}^{T}}\right]\right\}+\mu_{t},
$$

respectively, where subscripts indicate a partial derivative (other than $t$, which denotes time): for example, $T_{I}$ is simply the marginal tax rate; $M_{Q^{401 k}}$ is the marginal employer match rate for an additional dollar of $401(\mathrm{k})$ contribution; $\zeta_{y^{\prime}}$ is the change in the fraction of an IRA contribution that is deductible for an additional dollar of labor income; $V_{y}$ is the marginal utility of full income. ${ }^{10}$

\footnotetext{
${ }^{10}$ The complete set of first-order conditions is available upon request.
} 
We define the tax and match prices $p_{t}^{I R A} \equiv 1-T_{I t} \zeta_{t}, \quad p_{t}^{m} \equiv 1+M_{Q_{t}^{401 k}}$, and $p_{t}^{401(k)} \equiv 1-T_{I t}\left(1-\zeta_{y^{\prime} t} Q_{t}^{I R A}\right)$ and solve (20)-(22) to yield the following arbitrage condition for tax-deferred saving:

$$
\left(\frac{1}{p_{t}^{m}}\right)\left[p_{t}^{401(k)} V_{y}+\left(\eta_{t}^{L}-\eta_{t}^{0}\right)\right]=p_{t}^{I R A} V_{y}+\left(v_{t}^{L}-v_{t}^{0}\right) .{ }^{11}
$$

Intuitively, this equation says that the marginal value of an additional dollar of 401(k) saving must be just equal to that of a dollar of IRA saving at the optimum. In particular, on the left-hand side, for an employee who is not offered a match ( $\left.p^{m}=1\right)$, an additional dollar contributed to the $401(\mathrm{k})$ costs $p^{401(k)}$, the tax price, and is valued (in utils) according to the marginal utility of income, $V_{y}$, plus the shadow value of the contribution constraints if the employee is at one of the two 401(k) corner solutions. On the righthand side, one dollar contributed to the IRA costs $p^{I R A}$, the tax price, valued by the marginal utility of income, plus the shadow value of the contribution constraints if the employee is at one of the two IRA corner solutions. For an employee of a firm that offers matching contributions with a marginal match rate of $M_{Q^{401 k}}$, the left-hand side accounts for the fact that, with matching, only $1 /\left(1+M_{Q^{401 k}}\right)$ of a dollar must be foregone by the employee to get an incremental dollar in the 401(k) account. In the simplifying case of interior solutions for 401(k) and IRA saving, $\eta_{t}^{0}=0, \eta_{t}^{L}=0, v_{t}^{0}=0$, and $v_{t}^{L}=0$, (23)

\footnotetext{
${ }^{11}$ Importantly, $\zeta$ itself is a function of 401(k) participation, because 401(k) contributions reduce adjusted gross income (AGI), and AGI helps to determine the extent of IRA deductibility. Consequently, the tax price for $401(\mathrm{k})$ saving is defined as $p_{t}^{401 k} \equiv 1-\tau_{t}\left(1-\zeta_{y^{\prime}} Q_{t}^{I R A}\right)$, where $\zeta_{y^{l}}$ is the change in the fraction of an IRA contribution that is deductible for an additional dollar of 401(k) contribution.
} 
reduces to $p_{t}^{401(k)} / p_{t}^{m}=p_{t}^{I R A}$, which indicates that what matters for the optimal decision are the relative prices (or, equivalently, relative net returns) to the two types of saving.

\section{Identifying the EIS from 401(k) Participation}

Next, we show how we use the variation in employer matching schemes documented in section II, along with the arbitrage condition, to estimate the EIS in a theoretically coherent, non-linear budget-set econometric framework that accounts for the kinks induced by the caps on the generosity of the match. Specifically, let $\Delta \eta_{t} \equiv \eta_{t}^{L}-\eta_{t}^{0}$ and solve (23) for $\Delta \eta_{t}$ to yield

$$
\Delta \eta_{t}=\Delta p_{t} \cdot V_{y}+p_{t}^{m} \Delta v_{t},
$$

where, $\Delta v_{t} \equiv v_{t}^{L}-v_{t}^{0}$ and $\Delta p \equiv p^{m} p^{I R A}-p^{401(k)}$. The left-hand side of (24) is zero when the worker participates in the $401(\mathrm{k})$, negative if the worker does not participate, and is the latent variable in our discrete choice econometric model.

Because the EIS is defined as $(-) V_{y} / y V_{y y}$ (Browning, 1987), the key to implementing (24) is to specify the functional form for $V_{y}$, the marginal utility of income. We follow Blundell, Browning, and Meghir (1994) and flexibly model the indirect utility function by the following Box-Cox form

$$
V(\mathbf{q}, y ; \mathbf{z})=\frac{\left(\frac{y}{a(\mathbf{q})}\right)^{\lambda}-1}{\lambda} \cdot\left(\frac{\Psi(\mathbf{z})}{\ln [b(\mathbf{q})]}\right) .
$$

In (25), the $E I S$ is embodied in the parameter $\lambda$ :

$$
E I S \equiv(-) V_{y} / y V_{y y}=1 /(1-\lambda) .
$$


For example, if $\lambda=-0.5$, then the EIS is $0.67 .^{12}$ In the special case when $\lambda=0$, the indirect utility function becomes

$$
V(\mathbf{q}, y ; \mathbf{z})=\Psi(\mathbf{z}) \cdot \frac{\ln (y)-\ln [a(\mathbf{q})]}{\ln [b(\mathbf{q})]},
$$

which is a member of the class of the PIGLOG indirect utility functions (Muellbauer, 1976), that has been used extensively in the literature on consumption. With log utility, the EIS is 1.

The goal then is to use (24), (25), and the rich HRS data to estimate $\lambda$ and calculate the EIS. To do so, first note that from (25) the marginal indirect utility of income, $V_{y}$, is

$$
V_{y}=\left(\frac{\Psi(\mathbf{z})}{\ln [b(\mathbf{q})]}\right) y^{\lambda-1} a(\mathbf{q})^{-\lambda} .
$$

The factor $\Psi$ is a utility scaling factor that is a function of exogenous demographic characteristics, $\mathbf{z}$, and is modeled as

$$
\Psi_{i}(\mathbf{z})=\sum_{m} \psi_{m} z_{i, m},
$$

where $\mathbf{z}$ is an $m \times 1$ vector that includes a constant. Second, in (25) $a$ is homogeneous of degree one, and $b$ is homogeneous of degree zero and modeled as a Cobb-Douglas price aggregator

$$
b(\mathbf{q})=\prod_{k} q_{k}^{\gamma_{k}},
$$

\footnotetext{
${ }^{12}$ We refer to the $E I S$ in absolute value terms to make comparisons with the Euler-equation literature more straightforward.
} 
across the $k$ goods that enter the direct utility function, where $\sum_{k} \gamma_{k}=0$. Because we assume only two goods enter direct utility, leisure $(k=1)$ and consumption $(k=2)$, respectively, this implies $\gamma_{2}=-\gamma_{1}$, so that (30) reduces to

$$
b(\mathbf{q})=\omega^{\gamma_{k}}
$$

where $\omega \equiv q^{l} / q^{c}$ is the real relative price of leisure. Finally, the second term on the right-hand side of (24) is zero when IRA saving is at an interior solution, positive when constrained by the upper IRA limit, and negative when at the lower IRA limit (of zero). Therefore, let

$$
\kappa \equiv p^{m}\left(D^{L^{I R A}}-D^{0}\right)
$$

where $D^{L^{R A}}$ is a dummy variable that is one if IRA contributions are at the upper limit and zero otherwise, and $D^{0}$ is a dummy variable that is one if IRA contributions are zero and zero otherwise.

There are very few workers in our sample whose contributions equal the 401(k) plan maximum in the data. Therefore, we consider just the participation decision in the empirical analysis, so that the left-hand side of (24) collapses to $-\eta^{0}$, and (24), (28), (29), (31), and (32) combine to yield the following discrete choice econometric model of 401(k) participation:

$$
-\eta_{i j t}^{0}=\sum_{m} \delta_{1 m} z_{i, m} \frac{\Delta p_{i j t}}{y_{i j t} \ln \left(\omega_{i j t}\right)}\left(\frac{y_{i j t}}{a_{i j t}}\right)^{\lambda}+\delta_{2} \kappa_{i j t}+\boldsymbol{\alpha} \mathbf{x}_{i j t}+u_{j i t}
$$

and

$$
\begin{aligned}
& D_{i j t}^{401(k)}=1 \text { if } Q_{i j t}^{401(k)^{*}}>0 \Leftrightarrow-\eta_{i j t}^{0}=0 \\
& D_{i j t}^{401(k)}=0 \text { if } Q_{i j t}^{401(k)^{*}}=0 \Leftrightarrow-\eta_{i j t}^{0}<0,
\end{aligned}
$$


where $\delta_{1 m} \equiv \psi_{m} / \gamma_{1}, \quad Q_{i j t}^{401(k)^{*}}$ denotes the desired 401(k) contribution, $i$ and $j$ index individuals and 401(k) plans, respectively, and $u$ is the error term. Again, in (33) the EIS is embodied in $\lambda$, one of the parameters we will estimate using the HRS data. ${ }^{13}$

In the empirical analysis below, $\mathbf{z}$ includes a constant, the worker's education (in years), age, and dummy variables for whether the worker was married, white, and female, respectively. These demographic characteristics enter (33) parsimoniously and allow employer matching to have a heterogeneous effect on 401(k) participation for different demographic groups. The last term on the right-hand side of (33) includes $\mathbf{x}$, a vector that contains a constant and exogenous employer and employment characteristics. These are additional factors, explained below, that fall outside of the scope of this theoretical framework, but may affect 401(k) participation and, therefore, our estimates of the EIS.

\section{Estimation, Measurement, and Identification}

Because the caps on the generosity of employer matching induce kinks in the household's budget set, we apply non-linear budget-set techniques rooted in the public economics literature to estimate the EIS. Specifically, as an alternative to the maximumlikelihood piecewise-linear-budget-set estimation summarized in Hausman (1985) and Moffitt (1986, 1990) — and the recent, related non-parametric extensions by Blomquist and Newey (2002) —and the maximum likelihood differentiable-budget-constraint methodology of MaCurdy, Green, and Paarsch (1990), we employ instrumental-variable

\footnotetext{
${ }^{13}$ The primary distinction between this paper and Engelhardt and Kumar (forthcoming) is that in the latter we assumed $\lambda=0$ and used the associated PIGLOG preferences in (27). This had the virtue of yielding a linear-in-parameters econometric model—this can be seen by setting $\lambda=0$ in (33)—and made for substantially easier estimation. In addition, the focus of Engelhardt and Kumar (forthcoming) was on the impact of employer matching on 401(k) saving and on pension-plan design. In contrast, the current paper focuses on the estimation of the EIS.
} 
techniques from Engelhardt and Kumar (forthcoming) that linearize the budget set at the observed outcome to calculate the price and virtual-income terms and then instruments to correct for endogeneity, which also has a long history, but recent examples of which are Ziliak and Kniesner (1999, 2005).

To do so, the tax and match prices, $p^{I R A}, p^{m}$, and $p^{401(k)}$, the net wage, $\omega$, and income, $y$, must be calculated for all observed 401(k) outcomes in the dataset in order to construct the explanatory variables in (33). Because budget-set slopes are not defined at kink points, we use a variant of the method of Ziliak and Kniesner (1999) to calculate $p^{I R A}, p^{m}$, and $p^{401(k)}$ for each individual in the sample. First, we lay out the budget set in detail using the matching formulas in the SPDs, tax-rate information from NBER's TAXSIM calculator, and detailed household financial and demographic characteristics. In doing so, we minimize the impact of measurement error by the use of extensive administrative data, namely Social Security covered-earnings histories from 1951-1991 and W-2 earnings records for jobs held from 1980-1991 that were provided by SSA and IRS and linked to HRS respondents. The W-2s provide administrative data on earnings and 401(k) participation and contributions for 1991 (Cunningham and Engelhardt, 2002). We combine the W-2s, Social Security covered-earnings histories, and self-reported earnings histories to construct complete earnings histories from 1951-1991 for each member of our sample, which are used with Social Security and pension-benefit calculators to calculate pension wealth, accruals and changes in accruals, for 1991 and 1992, respectively, which are inputs into the net wage measure, $\omega$, which is quite complicated and described in detail in the data appendix. Second, we smooth the kinks in the budget set non-parametrically using kernel regression of the implicit (negative) tax 
rate from the employer matching and tax subsidy to contributions on AGI over the federal legally allowable range of $401(\mathrm{k})$ contributions of 0 to $\$ 9500$ using a second-order Gaussian kernel, with bandwidth chosen by Silverman's rule of thumb. Finally, because match and tax rates differ by worker, we do this on a household-by-household basis, so that the smoothing is household-budget-set specific. ${ }^{14}$

In accordance with life-cycle-consistent models, we measure income, $y$, as "full income,” $y$, expressed as

$$
y_{i t} \equiv \Delta W_{i t}^{T A}+w_{i t} L^{l}+y_{i t}^{o}-Q_{i t}^{401(k)}-Q_{i t}^{I R A C}+Q_{i t}^{I R A W}-T_{i t},
$$

which includes the market value of the leisure endowment. Under two-stage budgeting, the capital income and net (dis-)saving terms embodied in the change in assets are sufficient statistics for the past and the expectations of future variables (Blundell and Macurdy, 1999). However, because of the non-linear structure of matching and marginal tax rates, the tax and match prices, $p^{I R A}, p^{m}$, and $p^{401(k)}$, change depending upon the budget-set segment (either because the marginal match rate or tax rate changes), and, hence, the implicit tax liability from the employer-matching and tax subsidies will change depending upon the budget-set segment. Therefore, more precisely, we measure income as "virtual" full income, $y^{v}$, according to the respective budget segment, where we numerically integrate the estimated kernel-smoothed implicit tax function described above to calculate the associated implicit tax liability used to virtualize income. ${ }^{15}$

Finally, because the explanatory variables in (33) have components based on choice variables, we instrument to correct for endogeneity. Our instrument set, $\mathbf{Z}$,

\footnotetext{
${ }^{14}$ See the data appendix for details.

${ }^{15}$ See Engelhardt and Kumar (2006) for details.
} 
includes the vector of demographics, $\mathbf{z}$, and three additional variables drawn from the

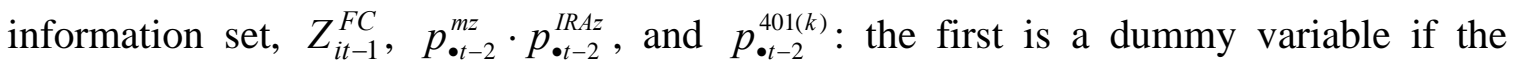
household was in poor financial condition in 1990, and the second and the third are based on "first-dollar" match and marginal tax rates for a synthetic taxpayer in 1989, where the subscript • denotes a synthetic taxpayer. There are two primary sources of variation in the instruments. First, $p^{m z}$ varies by plan, $j$. That is, we assume that the variation in matching schedules across plans is exogenous: in particular, there is no labor-market sorting of workers to firms that offer employer matching based on their responsiveness to rates of return. This is a standard assumption in the empirical pension-saving literature

(Bernheim, 2003). Second, $p^{I R A z}$ and $p^{401(k) z}$ vary across synthetic individuals because the tax function is non-linear in income and marital status. We describe the construction of the instruments and discuss the sources of identification in more detail in the data appendix.

\section{Estimation Results}

Because the econometric model in (33) is non-linear in parameters, we estimate the parameters by an extension of two-stage conditional maximum likelihood to nonlinear models as proposed by Smith and Blundell (1986), where $u \sim N\left(0, \sigma^{2}\right)$, on our sample of 1,042 workers in the HRS. This control-function approach also has been suggested for non-parametric models with endogeneity and selection by Das, Newey, and Vella (2003). Descriptive statistics for selected variables used in the empirical analysis are shown in Table 3. The participation rate in the sample is $56 \%$. 
One potential concern with this sample is that it may be non-random, because it is based on individuals for whom the HRS was able to obtain an SPD for the plan and administrative earning records. Therefore, we follow Engelhardt and Kumar (forthcoming, 2007) and correct our estimates for possible selection following Vella (1992) and using two exclusion restrictions based on IRS Form 5500 data: the incidence of pension-plan outsourcing by Census region, employment-size category, one-digit SIC code, and union status (union plan vs. non-union plan) cell in 1992; and the incidence of pension-plan consolidation due to mergers and acquisitions by cell from 1988-1992. We also include two other variables as exclusions in the selection equations-dummies for whether the individual left the job because the business closed or was laid off, respectively-which help to measure whether the employer possibly was in financial difficulty or failure at the time of severance. Outsourcing, consolidation, and business failure would have made it more difficult for the HRS to have obtained an SPD. We discuss construction of the exclusions and the selection equation in detail in the data appendix. ${ }^{16}$

Panel A of Table 4 presents the parameter estimates that account for selection and endogeneity with $95 \%$ bootstrapped confidence intervals in parentheses. ${ }^{17}$ Column 1 shows the estimates from the baseline specification, which does not include any

\footnotetext{
${ }^{16}$ The exclusions must be correlated with the likelihood of being in the sample, but uncorrelated with saving behavior. Because it is difficult to come up with exclusions that explain who consented to have their earnings records included in the HRS, we focused on exclusions that explain the likelihood of being linked to an SPD. Even though our exclusions focus on just one dimension of the selection, these variables are valid exclusions.

${ }^{17}$ All confidence intervals presented in the analysis below were based on 199 bootstrapped replications. (Efron and Tibshirani, 1986). The selection and first-stage equations were re-estimated for each bootstrap sample. We checked the sensitivity of the confidence intervals to the number of bootstrap replications and, for example, found that the standard errors were not appreciably different with more than 199 replications. Panel E shows the parameter estimates on the exclusion restrictions in the selection model. In particular, greater plan outsourcing, consolidation, business closure and layoffs significantly decrease the likelihood of having a matched SPD.
} 
additional covariates in the $\mathbf{x}$ vector in (19). Here, $\hat{\lambda}=-0.1985$, which implies an EIS of 0.83 . With a $95 \%$ confidence interval that ranges from 0.52 to 1.01 , we can reject the null hypothesis of an EIS of zero.

We show the estimates for the other main parameters in the econometric model in panel C. However, because the model is both structural and non-linear in parameters, it is difficult to interpret those parameters economically. Hence, to aid interpretation, we also present in panel D the marginal effects on 401(k) participation of each of the main economic variables in the model: the employer match rate, virtual full income, the marginal tax rate, and the net wage. As expected, the marginal effects of an increase in the match and tax rates are to raise participation, respectively. For example, an increase in the match of one dollar for each dollar of employee contribution raises participation by seven percentage points. This effect is statistically significant. ${ }^{18}$ In addition, the income effect is negative, as anticipated if consumption and leisure are normal goods: an increase in full income of $\$ 100,000$ lowers participation by one percentage point. This is statistically significant and suggests that participation is quite income-inelastic. These marginal effects are consistent with the results in Engelhardt and Kumar (forthcoming).

\subsection{Robustness Checks and Extensions}

One potential limitation of this specification is that firms may offer employer matching contributions as a way to try to avoid failing federal pension non-discrimination rules because they have low-saving employees (McGill, et al., 1996). In addition, firms that match may adopt other plan features to stimulate employee saving (e.g., allow for

\footnotetext{
${ }^{18}$ The confidence intervals for the marginal effects are not shown, but available upon request.
} 
borrowing against plan balances, self-directed investment, offer after-tax saving options, offer retirement seminars, etc.) or offer different fringe benefit packages that might affect saving behavior than firms that do not match. Omission of these factors from the specification might impart bias to our estimates of the EIS.

Therefore, in column 2, we add to the baseline specification two sets of additional explanatory variables: 1) fringe benefits offered: dummy variables for whether the firm offered long-term disability and group term life insurance, respectively, as well as the number of health insurance plans, number of retiree health insurance plans, weeks paid vacation, and days of sick pay; 2) other plan characteristics: dummy variables for whether the 401(k) allowed borrowing, hardship withdrawals, self-directed investment, had an after-tax saving option, a 401(k) contribution limit less than the federal limit, respectively, whether the firm offered other traditional pensions, and a measure of whether similar firms offering 401(k)s faced substantial non-discrimination "pressure" that we developed in Engelhardt and Kumar (forthcoming). ${ }^{19}$ Now, $\hat{\lambda}=-0.3108$, which implies an $E I S$ of 0.76 . The $95 \%$ confidence interval for the $E I S$ ranges from 0.47 to 1.26 and encompasses 1 , which represents log utility.

In the remaining columns, we enter additional variables into the specification and allow for interactions to check the robustness of the estimates. Specifically, in column 3, we add dummy variables for firm-size category, union, and region and their interactions

\footnotetext{
${ }^{19}$ Specifically, this measure is the share of workers with earnings above the federal threshold for the definition of a "highly-compensated" employee under federal non-discrimination regulations in the respondent's Census-region-by-employment-size-category-by-one-digit-SIC-code-by-union-status cell in 1989, constructed from the March CPS, and weighted by the difference in combined federal and state marginal tax rates on earnings for the median highly- and non-highly-compensated workers in the cell to reflect the value a highly-compensated worker would put on a dollar of tax-deferred salary through a 401(k) relative to that for a non-highly-compensated worker. See Engelhardt and Kumar (forthcoming) for details.
} 
with the fringe benefits and plan characteristics. The estimate of $\lambda$ for this specification is -0.2534 and changes very little from that in column 2. It implies an EIS of 0.79 .

We show the richest specification in column 4, where we include additional employment characteristics: dummy variables for both the worker and spouse for whether the firm offered a retirement seminar, discussed retirement with co-workers, whether responsible for the pay and promotion of others, the number of supervisees, spousal pension coverage, a full set of occupation dummies, and interactions of the occupation dummies with the fringe benefits, plan characteristics, and other employment characteristics. These additional controls have little impact on the results, with $\hat{\lambda}=-0.3534$, which implies an EIS of 0.74 . The $95 \%$ confidence interval ranges from 0.37 to 1.21 .

\section{Conclusion}

In this paper, we depart from the Euler-equation methods from the previous literature and take a novel approach to show how a life-cycle-consistent econometric specification of employee 401(k) participation can be used to generate new estimates of the EIS. Our key insight is that substantial variation in employer matching provides large, plausibly exogenous variation in the effective rate of return that can be used to identify the EIS. Using this variation and very rich administrative data, and for the richest specification (column 4, Table 4), we estimate the EIS to be 0.74 . The $95 \%$ confidence interval ranges from 0.37 to 1.21 . Our estimates are remarkably robust to a large set of control variables and provide new evidence that consumers are fairly 
responsive to changes in the effective rate of return when making saving and consumption decisions.. ${ }^{20}$

Although based on a different methodology, our findings are consistent with the point estimates of Attanasio and Weber (1995) and Ziliak and Kniesner (2005), but substantially larger than those by Hall (1988), Dynan (1993), and Barsky, Kimball, Juster, and Shapiro (1997). Because many workers with 401(k)s invest in equities in their accounts, our results are also consistent with the findings of Attanasio, Banks, and Tanner (2002), Vissing-Jorgensen (2002), and Vissing-Jorgensen and Attanasio (2003) that the EIS for stockholders is high. While those studies treated asset ownership as exogenous, our estimate of the EIS comes from the estimation of the decision to own taxdeferred assets itself.

\footnotetext{
${ }^{20}$ While our point estimates are smaller than the instrumental-variable estimates in Gruber (2006), whose instrumental-variable estimation approach used variation in net rates of return from changes to marginal tax rates induced by tax reforms, his $95 \%$ confidence intervals encompass ours, so that, in a statistical sense, our results do not differ from his.
} 


\section{References}

Attanasio, Orazio and Martin Browning, "Consumption over the Life Cycle and the over the Business Cycle,” American Economic Review 85:5 (1995): 1118-1137.

Attanasio, Orazio and Guglielmo Weber, "Intertemporal Substitution, Risk Aversion and the Euler Equation for Consumption,” Economic Journal 99 (1989): 59-73.

Attanasio, Orazio and Guglielmo Weber, "Consumption Growth, the Interest Rate and Aggregration,” Review of Economic Studies 60 (1993): 631-649.

Attanasio, Orazio and Guglielmo Weber, "Is Consumption Growth Consistent with Intertemporal Optimization? Evidence from the Consumer Expenditure Survey," Journal of Political Economy 103 (1995): 1121-1157.

Attanasio, Orazio, James Banks, and Sarah Tanner, "Asset Holding and Consumption Volatility,” Journal of Political Economy 110 (2002): 771-792.

Barsky, Robert B., Miles S. Kimball, F. Thomas Juster, and Matthew D. Shapiro, "Preference Parameters and Behavioral Heterogeneity: An Experimental Approach in the Health and Retirement Study,” Quarterly Journal of Economics 112:2 (1997): 537-579.

Bernheim, B. Douglas, “Taxation and Saving,” in Alan J. Auerbach and Martin Feldstein, eds., Handbook of Public Economics, Volume 3 (Amsterdam: North Holland), 2003, pp. 1173-1249.

Blomquist, Soren, and Whitney Newey, "Nonparametric Estimation with Nonlinear Budget Sets,” Econometrica 70 (2002): 2455-2480.

Blundell, Richard, Martin Browning, and Costas Meghir, "Consumer Demand and the Life-Cycle Allocation of Expenditures,” Review of Economic Studies 61:1 (1994): 57-80.

Blundell, Richard, and Thomas MaCurdy, "Labor Supply: A Review of Alternative Approaches,” in Orley Ashenfelter and David Card, eds., Handbook of Labor Economics, Volume 3A, (Amsterdam: North Holland), 1999, pp. 1559-1695.

Blundell, Richard, Costas Meghir, and Pedro Neves, "Labour Supply and Intertemporal Substitution,” Journal of Econometrics 59 (1993): 137-160.

Browning, Martin, "Which Demand Elasticities Do We Know and Which Do We Need to Know for Policy Analysis?” Mimeo., McMaster University, 1987.

Browning, Martin, Angus Deaton, and Margaret Irish, “A Profitable Approach to Labor Supply and Commodity Demands over the Life-Cycle,” Econometrica 55:3 (1985): 503544. 
Browning, Martin, and Annamaria Lusardi, "Household Saving: Micro Theories and Micro Facts,” Journal of Economic Literature 34:4 (1996): 1797-1855.

Carroll, Christopher, "Death to the Log-Linearized Euler Equation! (And Very Poor Health to the Second-Order Approximation)," Advances in Macroeconomics 1:1 (2001), Article 6.

Choi, James J., David Laibson, Brigitte C. Madrian, and Andrew Metrick, "Defined Contribution Pensions: Plan Rules, Participant Decisions, and the Path of Least Resistance," in James M. Poterba, ed., Tax Policy and the Economy, Vol. 16 (Cambridge, MA: MIT Press), 2002.

Choi, James J., David Laibson, Brigitte C. Madrian, and Andrew Metrick, "Optimal Defaults,” American Economic Review 93:2 (2003): 180-185.

Choi, James J., David Laibson, Brigitte C. Madrian, and Andrew Metrick, "For Better or Worse: Default Effects and 401(k) Savings Behavior," in David A. Wise, ed., Perspectives in the Economics of Aging (Chicago: University of Chicago Press), 2004, pp. 81-125.

Coile, Courtney, and Jonathan Gruber, "Social Security and Retirement," NBER Working Paper No. 7830, 2000.

Cunningham, Christopher R., and Gary V. Engelhardt, "Federal Tax Policy, Employer Matching, and 401(k) Saving: Evidence from HRS W-2 Records,” National Tax Journal, 55:3 (2002): 617-645.

Cunningham, Christopher R., Gary V. Engelhardt, and Anil Kumar, "Measuring Pension Wealth," in Olivia Mitchell, Beth Soldo, and Brigitte Madrian, eds. Redefining Retirement: How Will Boomers Fare?, Oxford University Press, 2007 (forthcoming).

Das, Mitali, Whitney K. Newey, and Francis Vella, "Nonparametric Estimation of Sample Selection Models,” Review of Economic Studies 70:1 (2003): 33-63.

Dynan, Karen, “How Prudent Are Consumers?,” Journal of Political Economy 101 (1993): 1104-1113.

Efron, Bradley, and Robert Tibshirani, "Bootstrap Methods for Standard Errors, Confidence Intervals, and Other Measures of Statistical Accuracy,” Statistical Science 1 (1986): 54-77.

Engelhardt, Gary V. and Anil Kumar, "Employer Matching and 401(k) Saving: Evidence from the Health and Retirement Study,” NBER Working Paper No. 12447, 2006.

Engelhardt, Gary V. and Anil Kumar, "Employer Matching and 401(k) Saving: Evidence from the Health and Retirement Study,” Journal of Public Economics, forthcoming. 
Engelhardt, Gary V. and Anil Kumar, "Pensions and Household Wealth Accumulation," Mimeo, Syracuse University, 2007.

Feenberg, Daniel, and Elisabeth Coutts, “An Introduction to the TAXSIM Model," Journal of Policy Analysis and Management 12 (1) (Winter) (1993): 189-194.

Gorman, W.M., “Separable Utility and Aggregation,” Econometrica 27:3 (1959): 469481.

Gruber, Jonathan, "A Tax-Based Estimate of the Elasticity of Intertemporal Substitution,” NBER Working Paper No. 11945, 2006.

Gustman, Alan L., Olivia S. Mitchell, Andrew A. Samwick, and Thomas L. Steinmeier, "Pension and Social Security Wealth in the Health and Retirement Study," in Wealth, Work, and Health: Innovations in Measurement in the Social Sciences, James Smith and Robert Willis, eds. (Ann Arbor: University of Michigan Press) 1999, pp. 150-208.

Hall, Robert, "Intertemporal Substitution in Consumption,” Journal of Political Economy 96 (1988): 339-57.

Hausman, Jerry A., "The Econometrics of Nonlinear Budget Sets," Econometrica (November) 53 (1985), 1255-1282.

Ibbotson Associates, Stocks, Bonds, Bills and Inflation, 2003 Yearbook (Chicago: Ibbotson Associates), 2003.

Ludvigson, Sydney, and Christina H. Paxson, "Approximation Bias in Linearized Euler Equations,” Review of Economics and Statistics 83:2 (2001): 242-256.

MaCurdy, Thomas E., David Green, and Harry Paarsch, "Assessing Empirical Approaches for Analyzing Taxes and Labor Supply,” Journal of Human Resources 25 (Summer 1990): 415-90.

McGill, Dan M., Kyle N. Brown, John J. Haley, and Sylvester J. Schieber, Fundamentals of Private Pensions, Seventh Edition (Philadelphia: University of Pennsylvania Press), 1996.

Mitchell, Olivia, Jan Olson, and Thomas Steinmeier, "Construction of the Earnings and Benefits File (EBF) for Use with the Health and Retirement Survey," HRS/AHEAD Documentation Report No. DR-001, Institute for Social Research, University of Michigan, 1996.

Moffitt, Robert A., “The Econometrics of Piecewise-Linear Budget Constraints,” Journal of Business and Economic Statistics 4 (1986): 317-328. 
Moffitt, Robert A., "The Econometrics of Kinked Budget Constraints," Journal of Economic Perspectives 4 (1990): 119-139.

Muellbauer, John, "Community Preferences and the Representative Consumer," Econometrica 44:5 (1976): 979-999.

Mulligan, Casey, "Capital, Interest, and Aggregate Intertemporal Substitution,” NBER Working Paper No. 9373, 2002.

Skinner, Jonathan, "Variable Lifespan and the Intertemporal Elasticity of Consumption," Review of Economics and Statistics 67:4 (1985): 616-623.

Smith, Richard J., and Richard W. Blundell, "An Exogeneity Test for a Simulaneous Equation Tobit Model with an Application to Labor Supply," Econometrica 54:3 (1986): 679-686.

Vella, Francis, "Simple Tests for Sample Selection Bias in Censored and Discrete Choice Models," Journal of Applied Econometrics 7:4 (1992): 412-421.

Vissing-Jorgensen, Annette, "Limited Asset Market Participation and the Elasticity of Intertemporal Substitution,” Journal of Political Economy 110 (2002): 825-853.

Vissing-Jorgensen, Annette, and Orazio Attanasio, "Stock-Market Participation, Intertemporal Substitution, and Risk Aversion,” American Economic Review 93:2 (2003): 383-391.

Yogo, Motohiro, "Estiamting the Elasticity of Intertemporal Substitution when Instruments are Weak," Review of Economics and Statistics 86:3 (2004): 797-810.

Ziliak, James, and Thomas Kniesner, "Estimating Life Cycle Labor Supply Tax Effects," Journal of Political Economy 107 (April 1999): 326-359.

Ziliak, James P., and Thomas J. Kniesner, "The Effect of Income Taxation on Consumption and Labor Supply,” Journal of Labor Economics 23:4 (2005): 769-796. 


\section{Data Appendix}

This material that follows is from the appendix in Engelhardt and Kumar (forthcoming). It describes the construction of and gives background on the analysis dataset. The interested reader also should consult Engelhardt and Kumar (2006). The data are drawn from the first wave of the HRS, a nationally representative random sample of 51-61 year olds and their spouses (regardless of age), which asked detailed questions about wealth, demographics, and spousal characteristics in 1992, and household income, tax information, and IRA contributions in 1991. So, for the purposes of the empirical analysis, periods $t$ and $t+1$ refer to 1991 and 1992, respectively.

The sample consists of 1,042 individuals from wave 1 of the HRS who were employed in 1991, eligible for a 401(k), whose employer provided a SPD for the plan, and who had linked administrative $\mathrm{W}-2$ and Social Security earnings data. The restricted-access employer-provided SPDs are distributed as the HRS Wave 1 Pension Plan Detail Data Set (Gustman, Mitchell, Samwick, and Steinmeier, 1999). This dataset contains plan type, eligibility rules, benefit formulae, employer contribution and matching formulae, early and normal retirement dates, and other information described in the SPD, but not any information for individual employees. The W-2 data are distributed as the HRS Wages and Self-Employment Income in Covered and Non-Covered Jobs dataset (Mitchell, Olson, and Steinmeier, 1996). The dataset is a cross-section for 1991 because even though there are earnings and deferral data prior to 1991, there are no data on other income and wealth needed to construct full income prior to 1991 in the HRS. Some of the individuals in the sample worked in 1991 but were retired at the time of the first interview in 1992. Exclusion of these individuals had no impact on the estimation results.

There are four types of employer matching: fixed-rate, discretionary, profitsharing, and variable-rate matching. Because the extent of matching is not always known in advance to employees making deferral decisions in profit-sharing and discretionary plans, these plans were not included in our sample. The SPDs were used to construct the complete schedule of employer matching contributions for each individual in our sample and applied all relevant restrictions on plan eligibility in the SPD, including those due to tenure, hours, earnings, age, and vesting of the employer matching contributions.

Because workers' budget sets can have multiple kinks and, therefore, multiple points of non-differentiability, from changes in match and marginal tax rates, a smooth, differentiable budget set around all kink points was constructed, following the methodology of MaCurdy, Green, and Paarsch (1990). Specifically, kernel regression of the implicit subsidy from employer matching and tax deductibility on the set of potential contributions from 0 to $\$ 9500$ (the federal maximum contribution in 1991) by $\$ 50$ increments was used to smooth the budget set, using the Gaussian kernel, $K(z)=(1 / \sqrt{2 \pi}) e^{-z^{2} / 2}$, with bandwidth chosen by Silverman's rule of thumb, $h=1.06 m / n^{1 / 5}$, where $m=\min \left(\sqrt{\operatorname{var}_{x}}, i q r_{x} / 1.349\right)$ and $i q r_{x}$ is the inter-quartile range. 
A smooth marginal implicit subsidy function was constructed from the kernel-regression estimates.

Ffull income, $y$, can be expressed as

$$
y_{i t} \equiv \Delta W_{i t}^{T A}+w_{i t} L^{l}+y_{i t}^{o}-Q_{i t}^{401(k)}-Q_{i t}^{I R A C}+Q_{i t}^{I R A W}-T_{i t},
$$

where $W^{T A}$ is taxable assets, $w$ is the gross wage, $L^{l}$ is the leisure endowment, $y^{o}$ is other income, $Q^{I R A C}$ is IRA contributions, $Q^{I R A W}$ is IRA withdrawals, and $T$ is taxes paid. The full income measure includes the market value of the leisure endowment. Under two-stage budgeting, the capital income and net (dis-)saving terms embodied in the change in assets, $\Delta A$, are sufficient statistics for the past and the expectations of future variables (Blundell and Macurdy, 1999). The respondent-reported income in wave 1 of the HRS referred to behavior in calendar year 1991; hence, $\Delta W$ was formed by using taxable wealth in 1992 taken from wave 1, taxable wealth in 1991, which was capitalized from 1991 capital income, a technique is commonly used in the literature, and $R^{T A}$ constructed from a weighted-average gross return based on returns in Ibbotson (2003). Tax rules from 1991 were used to construct an IRA phase-out calculator to determine $\zeta$ and $\zeta_{y^{\prime}}$, and household income, tax, and demographic data and NBER's TAXSIM calculator (Feenberg and Coutts, 1993) were used to construct marginal tax rates and taxes paid for each household. The estimated kernel-regression function was numerically integrated to obtain the dollar amount of implicit subsidy for every level of potential 401(k) contribution, which, with full income, was used to construct virtual full income along all portions of the budget sets.

The construction of the net wage, $\omega$, is described in detail in Engelhardt and Kumar (2006). For the private and public pension components in $\omega$, individuals were divided into cells based on exogenous demographic characteristics and the Social Security covered earnings from 1951-1991 and W-2 earnings records from 1980-1991 were used to calculate earnings histories for a synthetic-cell individual. These synthetic earnings histories were input as follows: 1) into the University of Michigan's Pension Estimation Program to calculate defined benefit pension wealth, accrual, and change in accrual for additional earnings for individuals with DB plans; 2) into the HRS DC/401(k) Calculator (Cunningham, Engelhardt, and Kumar, 2007) developed to calculate for individuals with defined contribution plans their DC pension wealth, non-matching contributions and the effect of additional earnings thereon, respectively; the impact of additional earnings on employer match on voluntary contributions; required 401(k) contributions and the impact of additional earnings thereon, respectively; and, 3) into the Social Security benefit calculator developed by Coile and Gruber (2000) to calculate Social Security wealth, accrual, and change in accrual for additional earnings. The effect of additional earnings on the employer match to voluntary contributions was calculated assuming a 401(k) contribution of 50 dollars for all individuals (regardless of actual contribution level).

Finally, the sample is likely non-random because it is based on individuals for whom the HRS was able to obtain 1) an employer-provided SPD for the 401(k) plan, and 
2) permission from the individual to match SSA covered earnings and IRS W-2 earnings histories. To understand the exclusion restrictions that were developed, it is useful to note the manner in which the HRS obtained the SPDs and administrative earnings data. The HRS asked all respondents who reported being in a (current or past) pension-covered job to provide the name and address of the employer. To maintain respondent confidentiality, the HRS attempted to contact the employer, not about the respondent's pension(s), but more generally as part of a survey of pension providers in which the HRS requested copies of SPDs for the universe of pensions the employer provided (to all employees). The HRS then "matched" from this universe the appropriate pension(s) to the respondent based on the respondent's characteristics, e.g., union status, method of pay (hourly, salaried, commission, piece rate), occupation, tenure, etc. The "match" rates were well below 100 percent: 65 percent of those currently working in pension-covered jobs, 66 percent for the last job for those not working, and 35 percent for jobs held five years or longer prior to the current (last) job for those working (not working).

There are a number of important reasons for the failure to match an SPD to the respondent. First, the respondent may not have given correct employer name and address. Second, the HRS may have failed to receive the SPD because the employer may have refused to comply with the pension provider survey, the employer could not be located at the address given, or the employer went out of business or merged with another company and no longer existed under the name given by the respondent. Third, the employer may have submitted an SPD, but the HRS was unable to match the SPD to the respondent based on the plan detail and the respondent's characteristics. This is less likely for union and public sector workers, who are easy to identify and whose plans are easy to obtain, and more likely for workers whose employers had undergone mergers and acquisitions with subsequent plan modifications.

The exclusion restrictions were constructed as follows. First, Form 5500 data for 1988-1992 from the Department of Labor, Employee Benefit Security Administration, on the universe of pension plans with 100 or more participants and a 5 percent random sample of plans with less than 100 participants were obtained. Second, plans were divided into cells defined by Census region, employment size category, one-digit SIC code, year, and union status (union plan vs. non-union plan). The first exclusion is the incidence of pension plan outsourcing by cell in 1992, where outsourcing means the plan was administered by an entity other than the employer (weighted using sampling weights provided by DOL). The intuition here is that the HRS was less likely to have obtained an SPD from the employer if (on average in its cell) plan administration was outsourced, because more than one contact was needed (first the employer, then the plan administrator) to have received the SPD. (It may well have been that plans that were outsourced were better administered and, therefore, employers that outsourced were more likely to have returned the pension provider survey. However, this was likely more than offset because the SPD request was significantly less likely to have been fulfilled when multiple entities needed to be contacted.) The second exclusion was the incidence of pension plan consolidation due mergers and acquisitions by cell from 1988-1992. The intuition here is that the HRS was less likely either to have obtained an SPD from the employer or to have matched it to the employee if (on average in its cell) there had been a 
lot of plan consolidation, because plan names and detail were often changed upon consolidation. Two other variables were used as exclusions for pensions on past jobs in our selection equations: dummies for whether the individual left the job because the business closed or was laid off, respectively. These helped to measure whether the employer possibly was in financial difficulty at severance, which, if that resulted in a business failure, would have made it more difficult for the HRS to have obtained an SPD.

There were three important considerations in constructing the instruments. First, the instruments were drawn from the information set $\Omega_{t}$. Because $t$ is 1991, all information from 1989 and 1990 is in the information set and orthogonal to decisions made in 1991 under rational expectations. Second, because the observed marginal match and tax rates depend upon $401(\mathrm{k})$ and IRA contributions, $p^{m z} \cdot p^{I R A z}$ and $p^{401 k z}$ are based on first-dollar measures: the employer match on the first dollar contributed and the marginal tax rate at which the first dollar contributed is deductible (which equals the tax rate on the last dollar of earnings). Third, to minimize dependence on individual-specific income and family size that might be correlated with saving behavior, the first-dollar rates were calculated for a synthetic individual of each marital status assumed to have no capital income, no children, under age 65, and taking the standard deduction-where marital status is assumed exogenous - with synthetic annual labor earnings constructed as follows: individuals were divided into cells based on exogenous demographic characteristics, and the cell mean gross hourly wage rate, $\bar{w}_{\boldsymbol{t}_{-2}}$, was multiplied by 2,000 annual hours, $\bar{H}$. Let the subscript $\bullet$ denote a synthetic measure and the superscript 0 denote a first-dollar measure, then

$$
p_{\bullet j}^{m z} \cdot p_{\bullet t-2}^{I R A z} \equiv\left(1+M_{Q^{401 k} \cdot j}^{V 0}\right) \cdot\left(1-T_{I \bullet t-2}^{0} \zeta_{\bullet t-2}^{0}\right)
$$

and

$$
p_{\bullet t-2}^{401 k z} \equiv 1-T_{I \bullet t-2}^{0}\left(1-\zeta_{y}^{0}{ }^{l}{ }_{\bullet t-2} \bar{Q}^{I R A}\right),
$$

where $\bar{Q}^{I R A}$ was set to one dollar for all individuals.

It is important to note that the tax function for $\Delta p$ in the endogenous variable is based on the tax system in 1991, but the tax function for the instruments is different because it is based on the tax system in 1989 (indicated by the subscript $t-2$ in (A.2)(A.3) above). For individuals with AGI below $\$ 50,000$, the functions were essentially the same, but differed for those above this level. Specifically, above this income level in 1989, the marginal tax rate increased from 28 to 33 percent due to the phase-out of the personal exemption. However, the Budget Act of 1990 raised the top marginal tax rate to 31 percent and changed the phase-out of the personal exemption. Therefore, the nonlinearity in the instruments' tax function differs from that for the endogenous regressor due to the tax-law change, which is taken as exogenous to the individual. About 15 percent of the sample is affected by this differential non-linearity in the instruments. 
Table 1. Distribution of First-Dollar Match Rates as a Percentage of Contributions

(1)

\begin{tabular}{ccccc} 
First-Dollar Match Rate (\%) & $\begin{array}{c}\text { Number of } \\
\text { Plans }\end{array}$ & $\begin{array}{c}\text { Percent of } \\
\text { Plans }\end{array}$ & $\begin{array}{c}\text { Number of } \\
\text { Individuals }\end{array}$ & $\begin{array}{c}\text { Percent of } \\
\text { Individuals }\end{array}$ \\
\hline 0 to 24 & 9 & 4.3 & 11 & 3.0 \\
25 & 23 & 15.3 & 43 & 11.6 \\
26 to 49 & 5 & 2.4 & 9 & 2.4 \\
50 & 90 & 43.1 & 143 & 38.4 \\
51 to 99 & 22 & 8.1 & 34 & 12.4 \\
100 & 57 & 27.2 & 116 & 31.2 \\
200 & 3 & 1.4 & 4 & 1.1 \\
& & & & 100.0 \\
\hline
\end{tabular}

Note: Authors' calculations from the HRS restricted-access pension plan data for the 209 plans associated with the 372 of the 1,042 HRS individuals in the analysis sample in plans with matching provisions. 
Table 2. Cap on Matching Contributions, as a Percentage of Pay, for Plans that Offer Employer Matching in the Analysis Sample

\begin{tabular}{ccccc}
\hline $\begin{array}{c}\text { Cap on Employer Matching } \\
\text { Contributions } \\
\text { as a Percentage of Pay }\end{array}$ & $\begin{array}{c}(1) \\
\text { Number of } \\
\text { Plans }\end{array}$ & $\begin{array}{c}(2) \\
\text { Percent of } \\
\text { Plans }\end{array}$ & $\begin{array}{c}\text { Number of } \\
\text { Individuals }\end{array}$ & $\begin{array}{c}\text { Percent of } \\
\text { Individuals }\end{array}$ \\
\hline Less than 2\% & 7 & 3.3 & 10 & 2.7 \\
2 & 11 & 5.3 & 12 & 3.2 \\
2.5 & 1 & 0.5 & 1 & 0.3 \\
3 & 19 & 9.1 & 24 & 6.5 \\
3.75 & 1 & 0.5 & 4 & 1.0 \\
4 & 23 & 11.0 & 40 & 10.8 \\
5 & 17 & 8.1 & 53 & 0.3 \\
5.5 & 1 & 0.5 & 1 & 0.3 \\
5.7 & 1 & 0.5 & 1 & 29.3 \\
6 & 56 & 26.8 & 109 & 15.3 \\
Greater than 6\% & 32 & 15.3 & 57 & 16.1 \\
No Cap & 41 & 19.6 & 60 & 100.0 \\
Total & & & & 372 \\
\hline
\end{tabular}

Note: Authors' calculations from the HRS restricted-access pension plan data for the 209 plans associated with the 372 of the 1,042 HRS individuals in the analysis sample in plans with matching provisions. 
Table 3. Sample Means of Selected Variables in the Empirical Analysis Sample, Standard Deviations in Parentheses, Medians in Square Brackets

(1)

(2)

(3)

(4)

(5)

\begin{tabular}{|c|c|c|c|c|c|}
\hline Variable & Full Sample & $\begin{array}{c}\text { Subsample } \\
\text { without } \\
\text { Matches }\end{array}$ & $\begin{array}{c}\text { Subsample } \\
\text { with Matches }\end{array}$ & $\begin{array}{c}\text { Subsample with } \\
\text { Positive } \\
\text { Contributions }\end{array}$ & $\begin{array}{c}\text { Subsample } \\
\text { with Zero } \\
\text { Contributions }\end{array}$ \\
\hline $\begin{array}{l}\text { 401(k) Contributions (in } \\
1991 \text { dollars) }\end{array}$ & $\begin{array}{c}1377 \\
(1920) \\
{[500]}\end{array}$ & $\begin{array}{c}1232 \\
(1895) \\
{[100]}\end{array}$ & $\begin{array}{c}1640 \\
(1938) \\
{[900]}\end{array}$ & $\begin{array}{c}2446 \\
(1982) \\
{[1892]}\end{array}$ & $\begin{array}{c}0 \\
(0) \\
{[0]}\end{array}$ \\
\hline Match Rate (in percent) & $\begin{array}{c}23 \\
(37) \\
{[0]}\end{array}$ & $\begin{array}{l}0 \\
(0) \\
{[0]}\end{array}$ & $\begin{array}{c}65 \\
(32) \\
{[50]}\end{array}$ & $\begin{array}{c}28 \\
(38) \\
{[0]}\end{array}$ & $\begin{array}{c}17 \\
(33) \\
{[0]}\end{array}$ \\
\hline $\begin{array}{l}\text { After-Tax Wage } \\
\text { (in } 1991 \text { dollars per hour) }\end{array}$ & $\begin{array}{l}10.04 \\
(5.55) \\
{[8.92]}\end{array}$ & $\begin{array}{l}10.09 \\
(5.56) \\
{[9.12]}\end{array}$ & $\begin{array}{c}9.96 \\
(5.54) \\
{[8.51]}\end{array}$ & $\begin{array}{l}10.91 \\
(5.96) \\
{[9.66]}\end{array}$ & $\begin{array}{c}8.91 \\
(4.75) \\
{[8.23]}\end{array}$ \\
\hline Age (years) & $\begin{array}{l}54.9 \\
(5.2) \\
{[55.0]}\end{array}$ & $\begin{array}{l}54.9 \\
(5.1) \\
{[55.0]}\end{array}$ & $\begin{array}{l}54.8 \\
(5.4) \\
{[55.0]}\end{array}$ & $\begin{array}{l}54.7 \\
(5.0) \\
{[55.0]}\end{array}$ & $\begin{array}{l}55.1 \\
(5.5) \\
{[55.0]}\end{array}$ \\
\hline Education (years) & $\begin{array}{l}13.3 \\
(2.7) \\
{[13.0]}\end{array}$ & $\begin{array}{l}13.5 \\
(2.7) \\
{[13.0]}\end{array}$ & $\begin{array}{l}13.0 \\
(2.6) \\
{[12.0]}\end{array}$ & $\begin{array}{l}13.8 \\
(2.5) \\
{[14.0]}\end{array}$ & $\begin{array}{l}12.7 \\
(2.7) \\
{[12.0]}\end{array}$ \\
\hline Percent Female & 47 & 47 & 47 & 48 & 45 \\
\hline Percent White & 82 & 81 & 85 & 86 & 78 \\
\hline Number of Dependents & $\begin{array}{c}0.70 \\
(0.93) \\
{[0.0]}\end{array}$ & $\begin{array}{c}0.68 \\
(0.93) \\
{[0.0]}\end{array}$ & $\begin{array}{c}0.75 \\
(0.94) \\
{[0.0]}\end{array}$ & $\begin{array}{c}0.71 \\
(0.95) \\
{[0.0]}\end{array}$ & $\begin{array}{c}0.70 \\
(0.91) \\
{[0.0]}\end{array}$ \\
\hline Percent Married & 80 & 79 & 82 & 81 & 79 \\
\hline $\begin{array}{l}\text { Spouse's Education } \\
\text { (Years) }\end{array}$ & $\begin{array}{l}10.6 \\
(5.5) \\
{[12.0]}\end{array}$ & $\begin{array}{l}10.6 \\
(5.7) \\
{[12.0]}\end{array}$ & $\begin{array}{l}10.6 \\
(5.2) \\
{[12.0]}\end{array}$ & $\begin{array}{l}11.0 \\
(5.5) \\
{[12.0]}\end{array}$ & $\begin{array}{l}10.1 \\
(5.5) \\
{[12.0]}\end{array}$ \\
\hline $\begin{array}{l}\text { Percent with Plans that } \\
\text { Allow Borrowing }\end{array}$ & 36 & 19 & 68 & 42 & 29 \\
\hline $\begin{array}{l}\text { Percent with Plans that } \\
\text { Allow Hardship } \\
\text { Withdrawals }\end{array}$ & 4 & 4 & 5 & 6 & 2 \\
\hline
\end{tabular}




\begin{tabular}{|c|c|c|c|c|c|}
\hline Variable & Full Sample & $\begin{array}{c}\text { Subsample } \\
\text { without } \\
\text { Matches }\end{array}$ & $\begin{array}{c}\text { Subsample } \\
\text { with Matches }\end{array}$ & $\begin{array}{c}\text { Subsample } \\
\text { with Positive } \\
\text { Contributions }\end{array}$ & $\begin{array}{c}\text { Subsample } \\
\text { with Zero } \\
\text { Contributions }\end{array}$ \\
\hline $\begin{array}{l}\text { Percent with Plans that } \\
\text { Allow Self-Directed } \\
\text { Investment }\end{array}$ & 63 & 46 & 92 & 66 & 58 \\
\hline $\begin{array}{l}\text { Percent with Other } \\
\text { Pensions at the Firm }\end{array}$ & 47 & 53 & 34 & 45 & 48 \\
\hline $\begin{array}{l}\text { Percent with Plan Limit } \\
\text { less than Federal Limit }\end{array}$ & 80 & 73 & 92 & 76 & 85 \\
\hline $\begin{array}{l}\text { Percent with Plan that } \\
\text { Allows After-Tax Saving }\end{array}$ & 23 & 9 & 47 & 26 & 18 \\
\hline $\begin{array}{l}\text { Percent that had } \\
\text { Employer-Sponsored } \\
\text { Retirement Seminar }\end{array}$ & 23 & 23 & 23 & 25 & 20 \\
\hline $\begin{array}{l}\text { Percent with a Spouse } \\
\text { who has a Pension }\end{array}$ & 39 & 39 & 38 & 42 & 35 \\
\hline Percent in a Union & 34 & 39 & 27 & 28 & 43 \\
\hline Number of Observations & 1042 & 670 & 372 & 588 & 454 \\
\hline
\end{tabular}


Table 4. Selected Parameter Estimates, Marginal Effects, and Elasticities from Box-Cox Utility Function, Correcting for Selection and Endogeneity, 95 Percent Confidence Intervals in Brackets

\begin{tabular}{|c|c|c|c|c|}
\hline Measure & $(1)$ & $(2)$ & (3) & (4) \\
\hline \multicolumn{5}{|l|}{ A. Parameter Estimate of $\lambda$} \\
\hline$\lambda$ & $\begin{array}{l}-0.1985 \\
{[-0.81,0.02]}\end{array}$ & $\begin{array}{l}-0.3108 \\
{[-1.11,0.21]}\end{array}$ & $\begin{array}{l}-0.2534 \\
{[-1.05,0.31]}\end{array}$ & $\begin{array}{c}-0.3534 \\
{[-1.66,0.17]}\end{array}$ \\
\hline Elasticity of Intertemporal Substitution & $\begin{array}{c}0.8344 \\
{[1.01,0.52]}\end{array}$ & $\begin{array}{c}0.7629 \\
{[1.26,0.47]}\end{array}$ & $\begin{array}{c}0.7978 \\
{[1.45,0.48]}\end{array}$ & $\begin{array}{c}0.7386 \\
{[1.21,0.37]}\end{array}$ \\
\hline \multicolumn{5}{|l|}{ B. Additional Controls } \\
\hline Fringe Benefit and Plan Characteristics? & No & Yes & Yes & Yes \\
\hline Interaction of Firm Size with Fringe Benefits and Plan Characteristics? & No & No & Yes & Yes \\
\hline $\begin{array}{l}\text { Occupation and Interactions of Occupation with Demographics, Fringe } \\
\text { Benefits, Plan Characteristics, and Other Employment Characteristics? }\end{array}$ & No & No & No & Yes \\
\hline \multicolumn{5}{|l|}{ C. Selected Other Parameter Estimates } \\
\hline$\delta_{11} \quad$ (Constant) & $\begin{array}{l}-4.07 \\
{[-21.35,7.19]}\end{array}$ & $\begin{array}{c}-4.98 \\
{[-44.01,1.91]}\end{array}$ & $\begin{array}{c}-6.33 \\
{[-33.89,5.74]}\end{array}$ & $\begin{array}{c}-5.19 \\
{[-35.52,6.30]}\end{array}$ \\
\hline$\delta_{12} \quad$ (Age) & $\begin{array}{c}0.01 \\
{[-0.13,0.15]}\end{array}$ & $\begin{array}{c}0.04 \\
{[-0.11,0.23]}\end{array}$ & $\begin{array}{c}0.04 \\
{[-0.23,0.20]}\end{array}$ & $\begin{array}{c}0.06 \\
{[-0.13,0.27]}\end{array}$ \\
\hline$\delta_{13} \quad$ (Female) & $\begin{array}{c}0.04 \\
{[-0.60,1.47]}\end{array}$ & $\begin{array}{c}0.82 \\
{[-0.21,4.22]}\end{array}$ & $\begin{array}{c}0.99 \\
{[-0.71,3.84]}\end{array}$ & $\begin{array}{c}0.78 \\
{[-0.72,3.43]}\end{array}$ \\
\hline$\delta_{14} \quad$ (White) & $\begin{array}{c}0.81 \\
{[-0.51,3.29]}\end{array}$ & $\begin{array}{c}0.48 \\
{[-0.53,4.94]}\end{array}$ & $\begin{array}{c}0.36 \\
{[-1.18,4.32]}\end{array}$ & $\begin{array}{c}0.17 \\
{[-1.46,5.13]}\end{array}$ \\
\hline$\delta_{15} \quad$ (Married) & $\begin{array}{c}0.28 \\
{[-1.70,1.77]}\end{array}$ & $\begin{array}{c}0.61 \\
{[-0.96,2.50]}\end{array}$ & $\begin{array}{c}0.83 \\
{[-0.47,4.24]}\end{array}$ & $\begin{array}{c}0.64 \\
{[-1.02,3.03]}\end{array}$ \\
\hline$\delta_{16} \quad$ (Education) & $\begin{array}{c}0.34 \\
{[0.02,1.01]}\end{array}$ & $\begin{array}{c}0.20 \\
{[0.01,1.71]}\end{array}$ & $\begin{array}{c}0.30 \\
{[0.008,1.68]}\end{array}$ & $\begin{array}{c}0.13 \\
{[-0.012,1.33]}\end{array}$ \\
\hline$\delta_{2} \quad(\kappa)$ & $\begin{array}{c}0.04 \\
{[-1.38,1.31]}\end{array}$ & $\begin{array}{c}-0.17 \\
{[-1.83,0.85]}\end{array}$ & $\begin{array}{c}-0.12 \\
{[-1.84,1.15]}\end{array}$ & $\begin{array}{c}-0.37 \\
{[-2.04,1.40]}\end{array}$ \\
\hline
\end{tabular}




\begin{tabular}{|c|c|c|c|c|}
\hline Match Rate & 0.0706 & 0.0885 & 0.1150 & 0.1499 \\
\hline Full Income & -0.0106 & -0.0074 & -0.0125 & -0.0081 \\
\hline Net Wage & -0.0003 & -0.0002 & -0.0003 & -0.0002 \\
\hline Marginal Tax Rate & 0.0287 & 0.0182 & 0.0307 & 0.0197 \\
\hline Predicted Probability of Participation & 0.94 & 0.86 & 0.85 & 0.77 \\
\hline \multicolumn{5}{|c|}{ E. Parameter Estimates for Selection Term and Exclusion Restrictions in the Selection Equation } \\
\hline Selection Term & $\begin{array}{c}-0.63 \\
{[-1.38,0.14]}\end{array}$ & $\begin{array}{c}-0.63 \\
{[-1.30,0.04]}\end{array}$ & $\begin{array}{c}-0.48 \\
{[-1.49,0.13]}\end{array}$ & $\begin{array}{c}-0.35 \\
{[-1.06,0.58]}\end{array}$ \\
\hline \multicolumn{5}{|l|}{ Selection-Equation Exclusions: } \\
\hline Plan Administration Outsourcing & $\begin{array}{l}-0.38 \\
(0.10)\end{array}$ & $\begin{array}{l}-0.37 \\
(0.10)\end{array}$ & $\begin{array}{l}-0.44 \\
(0.11)\end{array}$ & $\begin{array}{l}-0.49 \\
(0.11)\end{array}$ \\
\hline Plan Consolidation & $\begin{array}{l}-0.58 \\
(0.15)\end{array}$ & $\begin{array}{l}-0.63 \\
(0.15)\end{array}$ & $\begin{array}{l}-0.73 \\
(0.16)\end{array}$ & $\begin{array}{l}-0.76 \\
(0.16)\end{array}$ \\
\hline Left Job Due to Business Closure & $\begin{array}{l}-0.16 \\
(0.07)\end{array}$ & $\begin{array}{l}-0.13 \\
(0.07)\end{array}$ & $\begin{array}{l}-0.15 \\
(0.07)\end{array}$ & $\begin{array}{l}-0.16 \\
(0.07)\end{array}$ \\
\hline Left Job Because Laid Off & $\begin{array}{c}0.03 \\
(0.08)\end{array}$ & $\begin{array}{l}-0.01 \\
(0.09)\end{array}$ & $\begin{array}{c}0.01 \\
(0.09)\end{array}$ & $\begin{array}{c}0.02 \\
(0.09)\end{array}$ \\
\hline
\end{tabular}

Note: Columns 1-4 of Panel A of this table present selected parameter estimates from (17) in the text estimating $\lambda$ using non-linear maximum likelihood. For all columns, the sample consists of 1,042 individuals. All the columns assume prices, net wage, and virtual income are endogenous, and correct for endogeneity using the instrumental variables discussed in the text. All columns correct for possible non-random selection into the sample using the exclusion restrictions discussed in the text. Bootstrapped 95 percent confidence intervals have been reported in square brackets for parameters estimated by nonlinear maximum likelihood, e.g., $\lambda$ and the EIS, to account for the two-step nature of estimation to correct for endogeneity and selection. Marginal effects evaluated at the mean of the regressors are shown in panel D are based on the parameter estimates in panel A, evaluated at the sample means. For the selection equation in panel E, standard errors are reported in parenthesis. Panel B presents the additional controls included. 